\title{
Premature Discharge of Battery
}

National Cancer Institute

\section{Source}

National Cancer Institute. Premature Discharge of Battery. NCI Thesaurus. Code C62864.

Battery discharging earlier than expected. 